\title{
TURKEY'S TRADE WITH WESTERN BALKANS: LOOKING BEYOND THE TURKISH FOREIGN POLICY
}

\author{
Gezim Jusufi* \\ Fatos Ukaj**
}

\begin{abstract}
In this paper, through the use of the model of trade gravity, the aim is to analyze the trade between Turkey and the countries of the Western Balkans, looking beyond Turkey's foreign policy. In Turkish foreign policy, trade with the region and investment in the region is of particular importance. Even economic-trade relations are among the main elements of Turkish foreign policy. The dependent variable represents Turkey's exports and imports to the Western Balkan countries for the period 2009-2019, while the independent variables are the GDP of Turkey and the Western Balkan countries, the distance between the capitals of Turkey and these countries, the number of the population of Turkey and these countries, the common language and colonial ties. Thus, through the Panel data for ten years period, the trade between Turkey and the Western Balkans has been analyzed. Turkey should make greater efforts to increase trade volume with the countries of the Western Balkans so that its interest in these countries does not remain only rhetoric but is concretized with adequate political and economic actions.
\end{abstract}

KEYWORDS: Western Balkans; Trade; Turkey; Gravity model; Foreign policy.

\section{INTRODUCTION}

The Western Balkans is a political and geographical term ${ }^{1}$ and includes the countries of the Balkan Peninsula that are not members of the European Union

\footnotetext{
* Gezim Jusufi, University of Prishtina, Prishtina, Kosovo; gezimi.gjilan@gmail.com.

** Fatos Ukaj, University of Prishtina, Prishtina, Kosovo; fatos.ukaj@uni-pr.edu.

1 Jusufi, G. et al.: The effect of product innovation on the export performance of Kosovo SMEs, Management: Journal of Contemporary Management Issues, 25 (2) 2020, p. 215-234.
} 
- EU. ${ }^{2}$ This region consists of 6 countries: Albania, Bosnia and Herzegovina, North Macedonia, Kosovo, Montenegro, and Serbia. Like other countries in transition, the countries of the Western Balkans are characterized by structural changes and macroeconomic instability. ${ }^{3}$ According to Jusufi and Lubeniqi, ${ }^{4}$ these countries have similar economic, political, and social indicators. It should be noted that the Balkans has always been one of the crossroads with a very high influence in the wider political and economic positions. ${ }^{5}$

These countries have suffered greatly in all aspects of economic, social, and political life. Some of these have suffered from inter-ethnic wars, while others from dictatorial communist regimes. ${ }^{6}$ Due to their fragile past, the countries of the Western Balkans have not yet completed the process of political and economic transition, ${ }^{7}$ and weak institutions are failing to address socio-economic problems ${ }^{8}$ especially poor industrial performance in these countries. ${ }^{9}$ The countries of this region aim to integrate into the EU. However, the EU has no common strategy set out to integrate the countries of the Western Balkans. In this situation, these countries experienced difficulties in implementing substantial democratic reforms, ${ }^{10}$ but there can not be a turning back of the path of democratization. ${ }^{11}$

2 Jusufi, G., Ukaj, M.: Migration and Economic Development in Western Balkan Countries: Evidence from Kosovo, Poslovna Izvrsnost/Business Excellence, 14 (1) 2020, p. 142.

3 Kastrati, A. et al.: Output gap in Transition Economies using Unobserved Component Method: The Case of Czech Republic, Estonia and Kosovo, Ekonomska Misao i Praksa/Economic Thought and Practice, (2) 2017, p. 477-500.

4 Jusufi, G., Lubeniqi, G.: An Overview of Doing Business in Western Balkan: The Analysis of Advantages of Doing Business in Kosovo and North Macedonia, ILIRIA International Review, 9 (2) 2019, p. 168.

5 Sela, Y., Maksuti, B.: The Social, Political and Economic changes in the Western Balkans: Managing diversity, SEEU Review, 11 (2), 2015, p. 110.

6 Jusufi, G., Bellaqa, B.: Trade Barriers and Exports between Western Balkan Countries, Naše Gospodarstvo/Our Economy, 65 (4), 2019, p. 74.

7 Jusufi, G., Ajdarpašić, S.: The Impact of EU Programmes on Financing Higher Education Institutions in Western Balkans - Evidence from Kosovo, LEXONOMICA Journal of Law and Economics, 12 (1) 2020, p. 125.

8 Qorraj, G.: Towards European Union or Regional Economic Area: Western Balkans at Crossroads, Naše Gospodarstvo/Our Economy, 64 (1) 2018, p. 15.

9 Qorraj, G., Jusufi, G.: EU vs Local Market Orientation: Western Balkan Entrepreneurs' Challenge, Entrepreneurial Business and Economics Review, 7(4) 2019, p. 22.

10 Lushaku-Sadriu, J.: Europeanisation through Conditionality and Deliberation, Australian and New Zealand Journal of European Studies, 11 (2) 2019, pp. 33.

11 Shkurti, G., Ozcan, S.: Main Challenges and Features of Democratization in the Balkans: Albania case, International Conference on Economic and Social Studies ICESOS'14, 2014, p. 195. 
All Western Balkan countries except Kosovo are high-middle-income countries. In this category are countries with gross national income per capita between $\$ 3,956$ and $\$ 12,235$. However, most countries in this region are at the bottom of this income group, between \$4,180 in Albania and \$ 5,310 in Serbia. Montenegro has the region's highest GNI per capita at $\$ 7,120$. Kosovo, the poorest country in the Western Balkans with a total gross national income per capita of $\$ 3,850$, is part of the lowest group of middle-income economies. ${ }^{12}$ Along with economic development, the development of democracy is necessary to have long-term stability and prosperity in the countries of this region. ${ }^{13}$

According to Muja and Gunar ${ }^{14}$ the countries of the Western Balkans which have better governance have experienced higher living standards. Improving GDP per capita in this region is also related to the success of these countries in improving citizen participation in the political system, ensuring political stability, ensuring effective governance, regulatory quality, combating corruption, and the rule of law. But a problem that hinders these countries in their economic and political progress is the problem of competitive authoritarian regimes ${ }^{15}$ which is still expressed in this region. ${ }^{16}$

Also, this region is still not able to achieve lasting peace and stability. Under international pressure, Kosovo and Serbia are urged to reach a historic reconciliation agreement. ${ }^{17}$ The dialogue between Kosovo and Serbia may improve regional stability and cooperation ${ }^{18}$ because it is the key problem that is holding these two states hostage to the bitter past of the nineties. The introduction of 10 percent tariffs on imports from Serbia and Bosnia and Herzegovina and the subsequent increase to 100 percent by Kosovo, was one of the many prob-

12 Dabrowski, M., Myachenkova, Y.: Research Report: The Western Balkans on the road to the European Union. Bruegel Policy Contribution, No. 4, Bruegel, Brussels, 2018, p. 4.

13 Sela, S., Shabani, L.: The European Union Politics in the Western Balkans, The Western Balkans Policy Review, 1 (2) 2011, p. 24.

14 Muja, M., Gunar, S.: Institutions and economic performance: Evidence from Western Balkans 1996-2016, IFAC-PapersOnLine, 52 (25) 2019, p. 287-292.

15 Bieber, F.: Patterns of competitive authoritarianism in the Western Balkans, East European Politics, 34 (3) 2018, p. 337-350.

16 Halili, Z.: Western Balkans Integration into European Union: Challenges and Consequences, Traektoriâ Nauki = Path of Science, 5 (8) 2019, p. 4001-4012.

17 Sallova, D.: The denationalization Policy of the International Community in Kosovo, Thesis, 8 (1) 2019, p. 159.

18 Kastrati, A.: The role of civil society in the European integration process in Kosovo: EU Mechanisms and instruments for NGO sector development. 37th International Academic Conference, Budapest, 2018, p. 55. 
lems which hinder the development of free trade in this region. ${ }^{19}$ The successful completion of this dialogue will eliminate authoritarian regimes and will enable the development of trade and economy with safer and faster steps.

The European Union (EU) has made a significant contribution to the economic and political stabilization of the Western Balkans region. But Turkey has also contributed to the overall well-being of the region and ethnic reconciliation. ${ }^{20}$ In almost all the countries of the Western Balkans, Turkey has great authority. Turkey's full membership in the EU will strengthen political stability and security in this region. It will also increase the EU's credibility in the eyes of the Balkan Muslim communities, which consider Turkey their main ally. This will make the EU more politically powerful in the region. ${ }^{21}$

The paper will test the following hypotheses:

H1: The common language between Turkey and the countries of the Western Balkans has a positive effect on foreign trade between these countries.

H2: Population is a significant indicator of trade between Turkey and the Western Balkan countries.

H3: The economic size or GDP of the partner countries has a positive effect on bilateral trade.

\section{RELATIONS BETWEEN TURKEY AND WESTERN BALKAN COUNTRIES}

Turkey is a country spreading through the Middle East, the Balkans, the Caucasus, Central Asia, the Caspian, the Mediterranean, the Gulf, and the Black Sea. Therefore, it needs to exert influence in all these regions and thus achieve a strategic role at the global level. The book that made a drastic change in Turkey's mentality was Stratejik Derinlik (in English: Strategic Depth): Turkey's International Position by Ahmet Davutoğlu. Since Davutoğlu became Turkey's Minister of Foreign Affairs in 2009, Strategic Depth has become a major ref-

19 Gashi, P., Berisha, B.: The Impact of 100\% Tariff on the Import of Goods from Serbia and Bosnia and Herzegovina, European Union: Kosovo, No. 2018/395-320, 2019, p. 21.

20 Brljavac, B.: Turkey Entering the European Union through the Balkan Doors: In the Style of a Great Power!?, Polemos: Journal of Interdisciplinary Research on War and Peace, 14 (27) 2011, p. 523.

21 Babuna, A.: European Integration, Bosnia-Herzegovina and Stability in the Western Balkans: A New Strategy, Perceptions, 19 (2) 2014, p. 23. 
erence for Turkey's new Foreign Policy. ${ }^{22}$ According to Bieber and Tzifakis, ${ }^{23}$ in terms of Turkish foreign policy priorities, the Western Balkans is less important compared to the Middle East region. The country's relations with the EU, the US, and Russia are also more of a priority than the Western Balkans.

The phases of the modern involvement of the Turkish state in the Western Balkans can be summarized in 4 phases: The first phase began after the break-up of Yugoslavia. The Republic of Turkey began to engage in this region, covering the gap of 70 years of active engagement. The second phase was characterized by Turkey's active support for Western policies within the Euro-Atlantic framework, during the wars of the 1990s. The third phase began in 2002 with the rise of the ruling AKP. The fourth phase can be said to have started on July 15, 2016, when the coup against President Erdoğan failed..$^{24}$ In summary, Turkey's interest in the Western Balkans and Africa ${ }^{25}$ began to appear actively after the Cold War. Harxhi ${ }^{26}$ also emphasizes that the sudden social, political, and economic success of Turkey in the early nineties influenced it to deal intensively with the problems of the Balkan region.

The new Turkish foreign policy is based on historical tendencies and feelings of powerful action. Turkey has rejected a reactionary foreign policy approach. It has chosen to use regional and international priorities in foreign policy-making. ${ }^{27}$ Turkey considers Balkans a necessary geopolitical area for its security. ${ }^{28}$ The new Turkish foreign policy is part of the state project "Turkey's Strategic Vision 2023". According to this, Turkey will become an EU member as well as the 10th strongest economic force in the world. The restructuring and reform of the Western Balkan countries enable Turkey to develop economic cooperation with these countries and investments. Turkey's active policy in the

22 Šorović, M.: Importance and role of Turkey in the Western Balkans, Research in Social Change, 10 (2) 2018, p. 88-89.

23 Bieber, F., Tzifakis, N.: The Western Balkans as a Geopolitical Chessboard? Myths, Realities and Policy Options, Balkans in Europe Policy Advisory Group, 2019, p. 5-30.

24 Rašidagić, K.E., Hesova, Z.: Development of Turkish Foreign Policy Towards the Western Balkans with Focus on Bosnia and Herzegovina, Croatian International Relations Review, 26 (86) 2020, p. 98.

25 Enwere, Ch., Yilmaz, M.: Turkey's Strategic Economic Relations with Africa: Trends and Challenges, Journal of Economics and Political Economy, 1 (2) 2014, p. 215-230.

26 Harxhi, E.: An Overview of Turkish Foreign Policy in the Balkans, Insight Turkey, 19 (1) 2017, p. 33-42.

27 Bilgin, P.: Securing Turkey through western-oriented foreign policy, New perspectives on Turkey, (40) 2009, p. 105-125.

28 Lami, B.: Influence of Turkish Foreign Policy in Albania, European Journal of Multidisciplinary Studies, 2 (1) 2017, p. 99. 
Western Balkans is a reflection of its growing economic and trade success in the last decade. ${ }^{29}$

But according to Petrović and Reljic ${ }^{30}$ this region has a good history of cooperation with the EU. Therefore, the involvement of other countries, specifically Turkey, depends on whether they can offer products at more reasonable prices than the EU, or offer preferential terms as well as direct investment. It will be difficult for Turkey or other countries to offer these more than the EU. Turkish businesses, stimulated by politics, have engaged in several "strategic projects" in the Western Balkans, such as the construction of the Belgrade-South Adriatic Highway and the Durrës-Prishtina highway. Turkish economic ties with the Western Balkans have more political than business impetus.

Turkey's main barriers in the process of becoming an influential factor in the Western Balkans region are regional prejudices and fears, as well as the West's low support and prejudiced cooperation with Turkey. These factors could negatively affect Turkey increasing its influential role in the Western Balkans. ${ }^{31}$ Ekinci $^{32}$ states that in the long run, Turkey's influence in the Western Balkans region will depend heavily on the credibility it gains in this turbulent region. Creating the trust of these peoples in the Turkish state will enable Turkey to strengthen trade and political relations with the countries of this region. This is a precondition for Turkey's regional and economic integration in the Western Balkans. ${ }^{33}$

The best example of the concept of soft power, which was introduced by Joseph Nye in 2003, is that of relations between Turkey and the Western Balkans. Turkey's orientation in the Western Balkans is based on deeper ambitions than economic or trade ones. Turkey's regional policy can be seen as an extension of its soft power in the region, as a reflection of its role as a strong member of NATO, thus implementing cultural and socio-economic cooperation that has its origins in the common past under the rule of the Ottoman Empire. In the

\footnotetext{
29 Tahirovic, M.: Relations between Turkey and the Balkan Countries as in a Function of Improving the Regional Peace and Stability, Adam Akademi, 4 (2) 2014, p. 10.

30 Petrović, Ž., Reljić, D.: Turkish Interests and Involvement in the Western Balkans: A ScoreCard, Insight Turkey, 13 (3) 2011, p. 159-172.

31 Türbedar, E.: Turkey's New Activism in the Western Balkans: Ambitions and Obstacles, Insight Turkey, 13 (3) 2011, p. 149.

32 Ekinci, U. M.: A Golden Age of Relations: Turkey and the Western Balkans During the AK Party Period, Insight Turkey, 16 (1) 2014, p. 103-125.

33 Öniş, Z.: Multiple Faces of the "New" Turkish Foreign Policy: Underlying Dynamics and a Critique, Insight Turkey, 13 (1) 2011, p. 47-65.
} 
context of strengthening local Euroscepticism in the Western Balkans, Turkey may increase its influence even more in this region. ${ }^{34}$

Turkey's investments should increase significantly in all Western Balkan countries. ${ }^{35}$ This would create huge benefits for the region's 20 million population. But Turkey's direct investment in the Western Balkans accounts for less than $3 \%$ of its total direct investment. ${ }^{36}$ Turkey's position, size, and resources will enable it to increasingly play the role of balancer between troubled countries in the Western Balkans, such as Kosovo, Bosnia and Herzegovina, and Serbia. ${ }^{37}$ The Balkan region is seen by Turkey as its bridge to the western world. Therefore, Turkey's interest in the Western Balkans has been constant throughout the history of the modern Turkish Republic. Balancing regional power and great influence in the region should serve Turkey as a strategy to secure its path to the European Union. ${ }^{38}$

The integration of investments between the countries of the Western Balkans and Turkey is stronger than the integration of trade between these countries. The Western Balkan market is very attractive to Turkish firms. This provides an added incentive for Turkish firms to invest in the region, as costs are almost half those in Turkey and the price of industrial land is as low as five percent of industrial areas in the Marmara region. Turkey's private sector has low engagement in Montenegro and Serbia, medium in Bosnia and Herzegovina and Kosovo, and higher engagement in North Macedonia and Albania. ${ }^{39}$ Despite this, the concentration of Turkish businesses in this region must increase even more for Turkish foreign policy in this region to succeed.

34 Remiddi, A.: Turkey in the Western Balkans: Between Orientalist Cultural Proximity and Re-Orientation of Regional Equilibria, Balkan Social Science Review, 1, 2013, p. 228

35 Abazi, E.: Kosovo Independence: An Albanian Perspective, SETA Foundation for Political, Economic and Social Research, (11) 2008, p. 1-5.

36 Vračić, A.: Turkey's role in the Western Balkans, Berlin: Stiftung Wissenschaft und Politik -SWP- Deutsches Institut für Internationale Politik und Sicherheit, 2016, p. 13.

37 Rašidagić, K.E.: A Critical Analysis of Turkish Foreign Policy towards the Western Balkans, Turkish - Balkans Relations: The Future Prospects of Cultural, Political and Economic Transformations and Relations, 2013.

38 Mitrovic, M.: Turkish Foreign Policy towards the Balkans: The influence of traditional determinants on Davutoğlu's conception of Turkey - Balkan relations, GeT MA Working Paper, Department of Social Scienc-es, Humboldt-Universität zu Berlin, (10), 2014, p. 62.

39 Dursun-Özkanca, O.: Turkey and the European Union: Strategic Partners or Competitors in the Western Balkans?, Journal of Regional Security, 11 (1) 2016, p. 44. 


\section{FOREIGN TRADE BETWEEN TURKEY AND WESTERN BALKAN COUNTRIES}

According to Kirişci ${ }^{40}$ behind Turkish foreign policy lies the establishment of a trading state. This enables us to better understand Turkish foreign policy in relation to neighboring as well as distant countries. The choice of permanent trade policies is not possible because the interests of countries can change as a result of changing production structures and the level of economic development. ${ }^{41}$ Turkey's initiatives for the Western Balkans in the 1990s were aimed at boosting political and trade cooperation as well as protecting the region's population from aggressors at the time..$^{42}$ Kutlay ${ }^{43}$ emphasize the main activities of the soft power of Turkey's foreign policy are economy and trade.

The reasons for establishing economic relations between different countries through international trade are supply of goods and services from other countries, building economic, political, and social ties as well as increasing welfare. Therefore, economic cooperation and close relations are built with other countries to provide the above-mentioned opportunities. ${ }^{44}$ Kursunluoglu-Yarimoglu and Gur $^{45}$ claim that there have been no incentives from the Western Balkan countries to increase trade with Turkey. Meanwhile, there have been few incentives from Turkey that have not had the impact of increasing trade with the Western Balkans. Meanwhile, Turkey's trade with OECD countries is much more developed than with the Western Balkan countries. Especially intra-industry trade. ${ }^{46}$

Trade liberalization and market opening have greatly influenced the economic growth of the former communist countries of Central Europe. The countries

40 Kirişci, K.: The transformation of Turkish foreign policy: The rise of the trading state, New Perspectives on Turkey, (40), 2009, p. 29-57.

${ }_{41}$ Taşbaş1, A.: International trade and strategic behaviour: A game theoretical analysis of the trade dispute between Turkey and Russia, Economic Research/Ekonomska Istraživanja, 30 (1) 2017, p. 581.

42 Bechev, D.: Turkey in the Balkans: Taking a Broader View, Insight Turkey, 14 (1) 2012, p. 139.

43 Kutlay, M.: Economy as the 'Practical Hand' of 'New Turkish Foreign Policy': A Political Economy Explanation, Insight Turkey, 13 (1) 2011, p. 67-88.

44 Gökgöz, A. et al.: Analysis of International Trade between Turkey and Croatia, Poslovna izvrsnost/Business Excellence, 10 (2) 2016, p. 156.

45 Kursunluoglu-Yarimoglu, E., Gur, E.: Entry Mode to Western Balkans: An Implementation in Albania and Kosovo Markets, Mustafa Kemal University Journal of Graduate School of Social Sciences, 13 (33) 2016, p. 258-275.

46 Sen, A. et al.: Intra-Industry Trade between Turkey and OECD Countries: A Panel Data Analysis, Zagreb International Review of Economics \& Business, 12 (2) 2009, p. 73-86. 
of the Western Balkans region have also pursued trade liberalization policies, especially in relation to the EU and Turkey. However, due to the weak production base, economic growth in this region has not been as high as in Central European countries. ${ }^{47}$ In recent years, China and Turkey have managed to gain and expand market share in the region, while trade or imports from Russia have declined. ${ }^{48}$

Table 1: Share of Turkey in Western Balkan countries exports and imports in percent

\begin{tabular}{|l|c|c|}
\hline Country & $\begin{array}{c}\text { Share of Turkey in } \\
\text { countries exports, } \\
\text { (percent) }\end{array}$ & $\begin{array}{c}\text { Share of Turkey in } \\
\text { countries imports, } \\
\text { (percent) }\end{array}$ \\
\hline Albania & 1 & 9 \\
\hline Bosnia and Herzegovina & 3 & 5 \\
\hline Kosovo & 10 & 1 \\
\hline North Macedonia & 1 & 5 \\
\hline Montenegro & 3 & 4 \\
\hline Serbia & 2 & 4 \\
\hline
\end{tabular}

Source: International Trade Centre $(2020)^{49}$

Turkey's trade volume in Western Balkans increased as a result of trade liberalization in the region in line with European Union (EU) requirements, as well as the growth of the Turkish economy. Turkey aims to strengthen its cooperation with the Western Balkans through a "win-win" strategy. The geographical proximity of the Balkans will affect Turkey's EU integration through trade and investment. $^{50}$

\footnotetext{
47 Gashi, P.: Free Trade and FDI in Kosovo: Prospects for Integration into the EU and Turkish Production Networks, Turkish Economic Review, 4 (1) 2017, p. 86.

48 Kaloyanchev, P. et al.: Untapped Potential: Intra-Regional Trade in the Western Balkans, European Commission, (080) 2018, p. 20.

49 International Trade Centre: Bilateral trade between Turkey and Albania, Bosnia and Herzegovina, Kosovo, North Macedonia, Montenegro and Serbia in 2019, retrieved August 22, 2020.

50 Çakır, M.: An Economic Analysis of the Relationship between Turkey and the Balkan Countries, ADAM AKADEMI, 4 (2) 2014, p. 77-86.
} 
Table 2: Exports and imports of Turkey in Albania and Bosnia and Herzegovina

\begin{tabular}{|c|c|c|c|c|}
\hline \multirow{2}{*}{ Years } & \multicolumn{2}{|c|}{ Albania } & \multicolumn{2}{c|}{ Bosnia and Herzegovina } \\
\cline { 2 - 5 } & $\begin{array}{c}\text { Exports in } \\
\text { Euro }\end{array}$ & $\begin{array}{c}\text { Imports in } \\
\text { Euro }\end{array}$ & $\begin{array}{c}\text { Exports in } \\
\text { Euro }\end{array}$ & $\begin{array}{c}\text { Imports in } \\
\text { Euro }\end{array}$ \\
\hline 2009 & 196.065 .311 & 3.375 .504 & 161.920 .512 & 36.569 .865 \\
\hline 2010 & 180.112 .312 & 65.739 .045 & 168.283 .690 & 54.142 .029 \\
\hline 2011 & 194.596 .201 & 91.069 .846 & 192.791 .583 & 64.856 .072 \\
\hline 2012 & 198.610 .925 & 77.395 .563 & 195.836 .851 & 86.495 .844 \\
\hline 2013 & 200.798 .304 & 61.752 .802 & 206.733 .066 & 93.967 .865 \\
\hline 2014 & 240.267 .806 & 72.393 .413 & 242.679 .758 & 129.143 .793 \\
\hline 2015 & 259.509 .862 & 44.566 .012 & 263.858 .273 & 224.695 .537 \\
\hline 2016 & 274.992 .980 & 18.628 .693 & 278.615 .160 & 261.109 .624 \\
\hline 2017 & 342.493 .211 & 21.478 .049 & 308.012 .254 & 239.703 .003 \\
\hline 2018 & 347.043 .770 & 18.762 .131 & 355.757 .111 & 203.139 .626 \\
\hline 2019 & 422.232 .597 & 18.764 .038 & 396.673 .055 & 170.789 .170 \\
\hline
\end{tabular}

Source: Turkish Statistical Institute $2020^{51}$

Turkey has several advantages over other countries in trade with the Western Balkans. Geographical proximity, which reduces transportation costs, as well as the existing similarity in consumption habits between these countries, are the advantages of Turkey. Turkey has signed free bilateral trade agreements with North Macedonia (2000), Bosnia and Herzegovina (2003), Albania (2008), Serbia (2009), Montenegro (2010), and Kosovo (2013).

The European Union remains the main trading partner of the Western Balkans. ${ }^{52}$ The Western Balkans' trade openness to Turkey has increased in all countries in the last ten years. The share in total trade between the Western Balkan countries and Turkey was highest in Kosovo $8.8 \%$ and lowest in Serbia $2.9 \%$. While imports of Turkish goods dominate trade, especially exports of Serbian goods to Turkey have risen sharply recently to reach a third of total trade with Turkey. ${ }^{53}$ According to Kocaslan et al. ${ }^{54}$ trade between the Western

51 Turkish Statistical Institute: Foreign Trade by Partner Country, retrieved August 24, 2020.

52 Qorraj, G., Jusufi, G.: Does EU Trade Integration Support Export Promotion: Probit Analysis, Evidence from Kosovo, InterEULawEast: Journal for the International and European Law, Economics and Market Integrations, 8 (1) 2021, 75-90.

53 Hake, M., Radzyner, A.: Western Balkans: Growing economic ties with Turkey, Russia and China, Bank of Finalnd \& BOFIT Institute for Economies in Transition, 2019, p. 4-17.

54 Kocaslan, G. et al.: Is a Regional Trade Agreement with Balkan Countries Applicable for Turkey? A Time Series Analysis. Journal of Economic and Social Studies, 4 (1) 2014, p. 25-37. 
Balkans and Turkey can provide Turkey with many benefits, such as spillover and feedback effects.

Table 3: Exports and imports of Turkey in Kosovo and North Macedonia

\begin{tabular}{|c|c|c|c|c|}
\hline \multirow{2}{*}{ Years } & \multicolumn{2}{|c|}{ Kosovo } & \multicolumn{2}{c|}{ North Macedonia } \\
\cline { 2 - 5 } & $\begin{array}{c}\text { Exports in } \\
\text { Euro }\end{array}$ & $\begin{array}{c}\text { Imports in } \\
\text { Euro }\end{array}$ & $\begin{array}{c}\text { Exports in } \\
\text { Euro }\end{array}$ & $\begin{array}{c}\text { Imports in } \\
\text { Euro }\end{array}$ \\
\hline 2009 & 198.177 .656 & 7.264 .580 & 202.524 .046 & 28.704 .108 \\
\hline 2010 & 220.205 .668 & 10.266 .859 & 196.440 .036 & 39.484 .706 \\
\hline 2011 & 190.593 .762 & 7.264 .291 & 214.595 .967 & 66.174 .868 \\
\hline 2012 & 198.328 .009 & 7.095 .486 & 213.658 .477 & 79.646 .269 \\
\hline 2013 & 210.729 .162 & 7.490 .435 & 221.621 .327 & 61.481 .093 \\
\hline 2014 & 207.616 .930 & 9.627 .475 & 262.672 .466 & 59.650 .543 \\
\hline 2015 & 217.406 .721 & 7.096 .283 & 292.962 .420 & 72.987 .016 \\
\hline 2016 & 235.376 .946 & 7.678 .583 & 341.466 .968 & 74.510 .108 \\
\hline 2017 & 238.863 .483 & 7.494 .122 & 318.537 .836 & 89.286 .104 \\
\hline 2018 & 254.874 .617 & 7.879 .849 & 336.454 .068 & 91.375 .262 \\
\hline 2019 & 301.540 .100 & 6.946 .774 & 356.347 .713 & 87.188 .366 \\
\hline
\end{tabular}

Source: Turkish Statistical Institute $2020^{55}$

Turkey lacks a stable trade scheme. This scheme should include a solution to correct the problem of the structural deficit. This structural deficit stems from the mode of production and low levels of technology. As a result, Turkey produces products with poor added value. ${ }^{56}$ The countries of the Western Balkans also export goods as primary and intermediate goods. ${ }^{57}$ So, even these countries do not have special goods to export to the Turkish market.

\footnotetext{
55 Turkish Statistical Institute: Foreign Trade by Partner Country, retrieved August 24, 2020.

56 Babacan, M.: Whither an Axis Shift: A Perspective from Turkey's Foreign Trade, Insight Turkey, 13 (1) 2011, p. 155.

57 Gashi, P.: Human Capital and Export Decisions: The Case of Small and Medium Enterprises in Kosovo, Croatian Economic Survey, 16 (2) 2014, p. 91-120
} 
Table 4: Exports and imports of Turkey in Montenegro and Serbia

\begin{tabular}{|c|c|c|c|c|}
\hline \multirow{2}{*}{ Years } & \multicolumn{2}{|c|}{ Montenegro } & \multicolumn{2}{c|}{ Serbia } \\
\cline { 2 - 5 } & $\begin{array}{c}\text { Exports in } \\
\text { Euro }\end{array}$ & $\begin{array}{c}\text { Imports in } \\
\text { Euro }\end{array}$ & $\begin{array}{c}\text { Exports in } \\
\text { Euro }\end{array}$ & $\begin{array}{c}\text { Imports in } \\
\text { Euro }\end{array}$ \\
\hline 2009 & 18.804 .326 & 4.096 .864 & 218.923 .712 & 39.491 .818 \\
\hline 2010 & 20.810 .225 & 4.727 .992 & 229.025 .489 & 82.344 .897 \\
\hline 2011 & 19.369 .585 & 10.522 .144 & 254.604 .607 & 152.361 .856 \\
\hline 2012 & 22.664 .791 & 13.919 .794 & 295.966 .547 & 160.465 .043 \\
\hline 2013 & 21.957 .529 & 8.687 .831 & 332.165 .732 & 189.755 .826 \\
\hline 2014 & 26.524 .010 & 5.415 .533 & 382.164 .270 & 205.284 .431 \\
\hline 2015 & 34.500 .494 & 7.246 .713 & 443.716 .126 & 214.986 .101 \\
\hline 2016 & 46.601 .121 & 21.245 .599 & 525.023 .555 & 260.728 .413 \\
\hline 2017 & 53.063 .992 & 21.325 .466 & 633.660 .117 & 367.058 .897 \\
\hline 2018 & 67.459 .188 & 11.800 .387 & 734.725 .764 & 275.879 .628 \\
\hline 2019 & 114.026 .314 & 11.479 .159 & 827.781 .215 & 301.604 .437 \\
\hline
\end{tabular}

Source: Turkish Statistical Institute $2020^{58}$

Although Turkey and the Western Balkans region have tried to boost trade, the results are unsatisfactory. The countries of the Western Balkans need to redesign their trade policies concerning Turkey. In particular, these countries should focus more on marketing activities in the Turkish market. ${ }^{59}$ Qorraj and Jusufi $^{60}$ also emphasize that the products of the Western Balkan countries lack the right quality to take advantage of trade liberalization.

\section{THEORETICAL BACKGROUND: GRAVITY MODEL OF TRADE}

Some research has analyzed Turkey's trade with different countries through the gravity model. Gümüşcan and Kahveci ${ }^{61}$ have used the gravity model to decide bilateral trade between Turkey and the Western Balkan countries. In

58 Turkish Statistical Institute: Foreign Trade by Partner Country, retrieved August 24, 2020

59 Ekmen-Özçelik, S.: Trade Potential Between Balkan Countries And Turkey, International Balkan and Near Eastern Social Sciences Conference Series- IBANESS Conference Series-Prilep/Republic of Macedonia, 2016, p. 187-193

60 Qorraj, G., Jusufi, G.: The EU Stabilisation and Association Agreement for the Western Balkans: Between Challenges and Opportunities, Croatian International Relations Review, 24 (81) 2018, p. 51-68.

${ }^{61}$ Gümüşcan, I., Kahveci, M.: An Evaluation of Bilateral Trade between Turkey and Balkans: Based on Gravity Trade Model and Linder Hypothesis 241. IBAC- İstanbul Üniversitesi, 1, 2012, p. 361-371. 
their model, they have used variables such as the existence of the trade agreement, religion, and the voting results of the Eurovision Song Contest. According to them, geographical distance, and similarity in demand structures of the countries that are represented with the difference in GDP per capita of the countries contribute to understanding the trade formation between Western Balkans and Turkey.

According to the research through the application of the gravity model of Karagoz and Saray, ${ }^{62}$ Turkey's trade depends a lot on the size of the countries with which Turkey trades. Geographical distance also negatively affects trade between Turkey and partner countries. Mumcu-Akan and Engin-Balın ${ }^{63}$ through the model of gravity analyzed the impact of various agreements and customs unions on Turkey's trade. According to the results achieved by the gravity model, these trade agreements do not have a significant impact on the trade volume of Turkey, except for the increase of trade of some agricultural products.

Another study by Ülengin et al. ${ }^{64}$ used the gravity model to analyze the impact of quotas on Turkey's international trade and concluded that quotas have a negative impact on Turkish exports. Without quotas, Turkey's exports to the EU and other countries via road transport would be worth up to US \$ 10.6 billion. Another study conducted by Sandalcilar ${ }^{65}$ used panel data as well as the gravity model to estimate Turkey's trade with countries similar in size and economic strength. According to the results, the similar cultural traditions of the population and having a common border, positively affect Turkey's trade, while the geographical distance between the countries negatively affects Turkey's trade.

Through the gravity model, Civan et al ${ }^{66}$ researched the impact of diplomatic activities on Turkey's international trade. Thus, these authors, among the standard variables, have included the variable of the impact of government diplomatic activities on Turkey's international trade. To achieve its political goals, Turkey must strengthen its economic and trade influence in certain countries.

62 Karagoz, K., Saray, M. O.: Trade Potential of Turkey with Asia-Pacific Countries: Evidence from Panel Gravity Model, International Economic Studies, 36 (1) 2010, p. 19-26.

63 Akan, M. D. H., Engin-Balın, B.: The European Union-Turkey Trade Relations under the Influence of Customs Union, Journal of Economics, Business and Management, 4 (2), 2016, p. $155-160$.

64 Ülengin, F. et al.: Effects of quotas on Turkish foreign trade: A gravity model, Transport Policy, 2015.

65 Sandalc1lar, R. A.: Turkey's Trade Potential with the BRIC Countries: The Panel Gravity Model Approach, Journal of Yasar University, 75 (5) 2012, p. 4165-4175.

${ }_{66}$ Civan, A. et al.: The Effect of New Turkish Foreign Policy on International Trade, Insight Turkey, 15 (3) 2013, p. 107-122. 
Also, the increase in the per capita income of Turkey will have a positive impact on the growth of trade activities in Turkey. So, the increase of political activities will have a positive impact on the growth of international trade.

Yaşar and Korkaz ${ }^{67}$ analyzed trade between Turkey and the Western Balkan countries. According to them, the GDP of the Western Balkan countries and the GDP of Turkey have a significant impact on exports and imports of the Western Balkan countries. Geographical distance has a negative and significant impact on imports and exports. The common language and common historical past have an impact on Turkish exports to the region. Turkey's imports from this region are positively influenced by the EU membership process, by the common language, and the common historical past.

\section{DATA AND MODEL}

Newton's law of gravity can also be applied to the social sciences. Especially in the study of human behavior. This analysis is performed empirically. In the model of trade gravity, it is assumed that trade flows between the two countries depend on the economic size of each country expressed through Gross Domestic Product (GDP), and the geographical distance between these two countries, expressed through the distance between the capital towns of these two countries. ${ }^{68}$

According to Gashi et al. ${ }^{69}$, Gashi and $\mathrm{Pugh}^{70}$, the gravity model of trade flows has the following form:

$$
\text { Bilateral trade } \text { flows }_{\mathrm{ij}}=\frac{\operatorname{Size}(i) * \operatorname{size}(y)}{\operatorname{Distance}(i j)}
$$

Bilateral trade flows $\mathrm{ij}_{\mathrm{ij}}$ : Bilateral trade flows between countries (i) and (j); Economic Size (i): The economic size or GDP of the country (i);

Economic Size (j): The economic size or GDP of the country (j);

Distance (ij): The geographic distance between countries $(i)$ and $(j)$.

\footnotetext{
67 Yaşar, E., Korkaz, I.: Analysis of Foreign Trade between Turkey and the Balkan Countries with Gravity Model, The Journal of Kesit Academy, 3 (10) 2017, p. 382-407.

68 Peci, F. et al:: Determinants of Kosovo Trade: A Gravity Model Approach, South East European Journal of Economics and Business, 5 (2) 2010, p. 37.

69 Gashi, P. et al:: Kosovo - EU Trade Relations: A Dynamic Panel Poisson Approach, Applied Economics, 49 (27) 2017, p. 2642-2654.

70 Gashi, P., Pugh, G.: Kosovo's Trade with the European Union: Looking beyond the Stabilisation and Association Agreement, Kosovo Foundation for Open Society KFOS, 2015, p. 8-82.
} 
Our research will apply the gravity model through panel data. According to Park $^{71}$ longitudinal data provides observations on the same units in several different time periods. This data has more variability and allows more issues to be explored compared to cross-sectional or time-series data alone. A panel has the form of:

$$
X_{i t}, \quad i=1, \ldots, N, \quad t=1, \ldots, T
$$

Where $i$ is the individual or country dimension and $t$ is the time dimension. A general panel data regression model is written as:

$$
y_{i t}=\alpha+\beta^{\prime} x_{i t}+u_{i t}
$$

Our gravity model has this form, where in the first model the dependent variable represents Turkey's exports to the Western Balkan countries, while in the second model the dependent variable represents Turkey's imports from the Western Balkan countries.

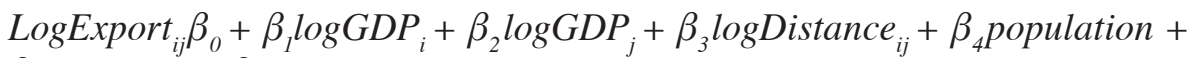
$\beta_{5}$ language $+\beta_{6}$ colonial link

LogImport $_{i j} \beta_{0}+\beta_{l} \log G D P_{i}+\beta_{2} \log G D P_{j}+\beta_{3} \log$ Distance $_{i j}+\beta_{4}$ population + $\beta_{5}$ language $+\beta_{6}$ colonial link

The statistics on Turkey's exports and imports to the Western Balkan countries are presented above. Meanwhile, below will be presented the statistics of the distance between the capital of Turkey Ankara and the capitals of the Western Balkan countries, as well as the economic size or GDP of Turkey and the countries of the Western Balkans. Also the population of Turkey and the countries of the Western Balkans.

${ }_{71}$ Park, M.H.: Practical Guides to Panel Data Modeling: A Step by Step Analysis Using Stata, International University of Japan Public Management \& Policy Analysis Program, 2011, p. 1. 
Table 5: Distance between capital towns of Western Balkans and Turkey

\begin{tabular}{|l|c|}
\hline \multicolumn{1}{|c|}{ Capitals } & Distance between capitals in km \\
\hline Ankara $\rightarrow$ Skopje & $1253 \mathrm{~km}$ \\
\hline Ankara $\rightarrow$ Tirana & $1550 \mathrm{~km}$ \\
\hline Ankara $\rightarrow$ Beograd & $1399 \mathrm{~km}$ \\
\hline Ankara $\rightarrow$ Sarajevo & $1607 \mathrm{~km}$ \\
\hline Ankara $\rightarrow$ Prishtina & $1343 \mathrm{~km}$ \\
\hline Ankara $\rightarrow$ Podgorica & $1581 \mathrm{~km}$ \\
\hline
\end{tabular}

Source: googlemap 2020

In this model, there are two dummy variables. The first variable concerns the use of the Turkish language in the countries of the Western Balkans. As it is known in some countries of the Western Balkans due to the Ottoman heritage and the Turkish minority the Turkish language is spoken. Among these six countries, only in Kosovo and North Macedonia is Turkish still spoken. So, if the common language is used, then the variable takes the value 1, while if it is not used, it takes the value 0 .

The other variable has to do with the common history with Turkey within the Ottoman rule. If the country has colonial ties with Turkey, it gets the value 1, while if it does not it gets the value 0 . From these countries, it can be said that only Montenegro has no colonial ties with Turkey, while other countries do. The number of observations in our case is 60 . Therefore, it would be appropriate to use Beck-Katz ${ }^{72}$ method to estimate our gravity model.

Table 6: GDP of Albania and Bosnia and Herzegovina in Euro

\begin{tabular}{|c|c|c|}
\hline Years & Albania & Bosnia and Herzegovina \\
\hline 2009 & $8,662.2$ & $12,679.3$ \\
\hline 2010 & $8,996.6$ & $12,968.9$ \\
\hline 2011 & $9,268.3$ & $13,411.8$ \\
\hline 2012 & $9,585.8$ & $13,407.5$ \\
\hline 2013 & $9,625.4$ & $13,691.8$ \\
\hline 2014 & $9,968.6$ & $13,988.3$ \\
\hline 2015 & $10,264.1$ & $14,617.4$ \\
\hline 2016 & $10,719.9$ & $15,289.9$ \\
\hline 2017 & $11,559.0$ & $16,042.4$ \\
\hline 2018 & $12,820.1$ & $17,099.7$ \\
\hline 2019 & $13,643.7$ & $17,908.3$ \\
\hline
\end{tabular}

Source: Eurostat $2020^{73}$

72 Beck, N., Katcz, N.J.: What to do (And not to do) with time-series cross-section data, American Political Science Review, 89 (3) 1995, p. 634-647.

73 GDP and main components, Eurostat, retrieved September 2, 2020. 
These tables reflect the GDP statistics for the Western Balkan countries, starting from Albania, Bosnia and Herzegovina, and so on. From these statistics, it can be understood that these countries generally have the same stage of economic development.

Table 7: GDP of Kosovo and North Macedonia in Euro

\begin{tabular}{|c|c|c|}
\hline Years & Kosovo & North Macedonia \\
\hline 2009 & 4.311 .2 & $6,766.5$ \\
\hline 2010 & $4,402.0$ & $7,108.3$ \\
\hline 2011 & $4,814.5$ & $7,544.2$ \\
\hline 2012 & $5,058.8$ & $7,584.8$ \\
\hline 2013 & $5,326.6$ & $8,149.6$ \\
\hline 2014 & $5,567.5$ & $8,562.0$ \\
\hline 2015 & $5,807.0$ & $9,072.3$ \\
\hline 2016 & $6,070.1$ & $9,656.5$ \\
\hline 2017 & $6,413.8$ & $10,038.3$ \\
\hline 2018 & $6,725.9$ & $10,698.1$ \\
\hline 2019 & $6,821.1$ & 10.579 .0 \\
\hline
\end{tabular}

Source: Eurostat $2020^{74}$

Despite the achievements, due to various crises of a global nature, such as the financial crisis and COVID19, the level of GDP growth has declined in these countries. This has led to an increase in extreme poverty in these countries, especially in Kosovo.

Table 8: GDP of Montenegro and Serbia in Euro

\begin{tabular}{|c|c|c|}
\hline Years & Montenegro & Serbia \\
\hline 2009 & $2,993.9$ & $32,486.2$ \\
\hline 2010 & $3,125.1$ & $31,545.8$ \\
\hline 2011 & $3,264.8$ & $35,431.7$ \\
\hline 2012 & $3,181.5$ & $33,679.3$ \\
\hline 2013 & $3,362.5$ & $36,426.7$ \\
\hline 2014 & $3,457.9$ & $35,467.5$ \\
\hline 2015 & $3,654.5$ & $35,715.5$ \\
\hline 2016 & $3,954.2$ & $36,723.0$ \\
\hline 2017 & $4,299.1$ & $39,183.3$ \\
\hline 2018 & $4,663.1$ & $42,855.5$ \\
\hline 2019 & 4.512 .2 & $45,911.6$ \\
\hline
\end{tabular}

Source: Eurostat ${ }^{75}$

74 GDP and main components, Eurostat, retrieved September 2, 2020.

75 GDP and main components, Eurostat, retrieved September 2, 2020. 
In addition to economic change, these countries have also experienced demographic change. Statistics show that these countries have started to have a slight population decline.

Table 9: Population of Albania and Bosnia and Herzegovina 2009-2019

\begin{tabular}{|c|c|c|}
\hline Years & Albania & Bosnia and Herzegovina \\
\hline 2009 & $2,936,355$ & $3,843,998$ \\
\hline 2010 & $2,918,674$ & $3,844,046$ \\
\hline 2011 & $2,907,361$ & $3,843,183$ \\
\hline 2012 & $2,903,008$ & $3,839,265$ \\
\hline 2013 & $2,897,770$ & $3,835,645$ \\
\hline 2014 & $2,892,394$ & $3,830,911$ \\
\hline 2015 & $2,885,796$ & $3,825,334$ \\
\hline 2016 & $2,875,592$ & $3,515,982$ \\
\hline 2017 & $2,876,591$ & $3,509,728$ \\
\hline 2018 & $2,870,324$ & $3,500,295$ \\
\hline 2019 & $2,862,427$ & $3,492,018$ \\
\hline
\end{tabular}

Source: Eurostat $2020^{76}$

The difficult economic and social situation has led to large numbers of young people leaving these countries in search of a better life in EU countries. Nepotism and the level of corruption have caused these young people to lose hope for a better life in these countries of this region.

Table 10: Population of Kosovo and North Macedonia 2009-2019

\begin{tabular}{|c|c|c|}
\hline Years & Kosovo & North Macedonia \\
\hline 2009 & $2,180,686$ & $2,048,619$ \\
\hline 2010 & $2,208,107$ & $2,052,722$ \\
\hline 2011 & $1,794,180$ & $2,057,284$ \\
\hline 2012 & $1,780,021$ & $2,059,794$ \\
\hline 2013 & $1,815,606$ & $2,062,294$ \\
\hline 2014 & $1,820,631$ & $2,065,769$ \\
\hline 2015 & $1,804,944$ & $2,069,172$ \\
\hline 2016 & $1,771,604$ & $2,071,278$ \\
\hline 2017 & $1,783,531$ & $2,073,702$ \\
\hline 2018 & $1,798,506$ & $2,075,301$ \\
\hline 2019 & $1,795,666$ & $2,077,132$ \\
\hline
\end{tabular}

Source: Eurostat $2020^{77}$

\footnotetext{
76 Population on 1 January, Eurostat, retrieved September 4, 2020.

77 Population on 1 January, Eurostat, retrieved September 4, 2020
} 
Kosovo, Albania, North Macedonia, and Bosnia and Herzegovina are facing high unemployment, which is contributing to the generation of ongoing social and economic crises. Trade is seen as a sector which with the increase of the level of exports would generate an increase of production and employment of these countries.

Table 11: Population of Montenegro and Serbia 2009-2019

\begin{tabular}{|c|c|c|}
\hline Years & Montenegro & Serbia \\
\hline 2009 & 617,157 & $7,334,937$ \\
\hline 2010 & 619,001 & $7,306,677$ \\
\hline 2011 & 619,850 & $7,251,549$ \\
\hline 2012 & 620,308 & $7,216,649$ \\
\hline 2013 & 620,893 & $7,181,505$ \\
\hline 2014 & 621,521 & $7,146,759$ \\
\hline 2015 & 622,099 & $7,114,393$ \\
\hline 2016 & 622,218 & $7,076,372$ \\
\hline 2017 & 622,387 & $7,040,272$ \\
\hline 2018 & 622,359 & $7,001,444$ \\
\hline 2019 & 622,182 & $6,963,764$ \\
\hline
\end{tabular}

Source: Eurostat $2020^{78}$

Turkey and EU countries are seen as potential markets for increasing exports of Western Balkan firms. Therefore, in order to increase the exports of these countries to EU countries and Turkey, adequate trade policies must be formulated. Firms must also have effective innovative processes of that according to Stojcic et al. ${ }^{79}$ this can be achieved through the creative skills of firms. Each economic sector has differences in terms of applying innovative processes.

\section{INTERPRETATION OF THE RESULTS}

In the first model, the dependent variable represents Turkey's exports to the Western Balkans, while in the second model the dependent variable represents Turkey's imports from this region. As can be seen from the results achieved, GDP is significant in both the export and import models. Also, the values of this variable are positive. This shows that Turkey's economic size or its GDP has a positive impact on trade with the Western Balkan countries.

\footnotetext{
78 Population on 1 January, Eurostat, retrieved September 4, 2020.

79 Stojcic, N. et al.: Creativity, innovation effectiveness and productive efficiency in the UK, European Journal of Innovation Management, 21 (4) 2018, p. 564-580.
} 
Table 12: Estimation Results

\begin{tabular}{|l|c|c|}
\hline & Model 1 & Model 2 \\
\hline \multirow{2}{*}{ Intercept } & -14.23 & -27.86 \\
& $(5.41)$ & $(13.26)$ \\
\hline \multirow{2}{*}{$\operatorname{logGDP}{ }_{\mathrm{i}}$} & $0.82^{* * *}$ & $1.19 * * *$ \\
& $(0.30)$ & $(0.93)$ \\
\hline \multirow{2}{*}{$\operatorname{logGDP}{ }_{\mathrm{j}}$} & $0.85^{* * *}$ & $1.18^{* * *}$ \\
& $(0.06)$ & $(0.53)$ \\
\hline \multirow{2}{*}{$\log \operatorname{listance}_{\mathrm{ij}}$} & $-0.90 * * *$ & $-1.49 * * *$ \\
& $(0.20)$ & $(0.16)$ \\
\hline \multirow{2}{*}{ population } & 2.63 & $-0.70 * * *$ \\
& $(2.39)$ & $(-0.58)$ \\
\hline \multirow{2}{*}{ language } & $0.89 * * *$ & $1.54 * * *$ \\
& $(0.33)$ & $0.21)$ \\
\hline \multirow{2}{*}{ colonial link } & 0.49 & $(0.19)$ \\
\hline $\mathrm{R}^{2}$ & $(0.26)$ & 0.91 \\
\hline Obstervations & 0.96 & 60 \\
\hline
\end{tabular}

*** significance at 0.01 level. In paranthesis are robust standard errors.

Source: Authors' own work. The figures used in the calculations are taken from the tables of exports and imports, distance, GDP and population included above.

The economic size of countries in international trade has a positive impact because a growing economy influences the growth of trade activities. Trade does not recognize political barriers, so only economic growth enables the elimination of political barriers and prejudices by opening opportunities for the development of trade at the international level. Geographical distance is significant in both models but has a negative sign. This shows that as distance increases, bilateral trade between Turkey and the Western Balkan countries decreases.

As for the population variable, only in the model of Turkish imports, it is significant. Even in this model, this variable has a negative sign, which shows its negative impact on Turkish imports. The use of a common language is of particular importance in both models, as this affects the growth of Turkish imports and exports in the region. Colonial or historical ties between Turkey and the countries of the Western Balkans do not represent significance in our models. Nevertheless, these have a positive relationship with the dependent variable. So, the common historical past of Turkey with this region positively affects the trade relations between these countries. 
Based on these results, it can be argued that the first hypothesis is supported. So the common language affects the trade relations between Turkey and the Western Balkans, in particular with North Macedonia and Kosovo. Turkish is spoken only in these two countries of the Western Balkans. So maybe these two countries have an advantage over the other four countries. Therefore, firms from North Macedonia and Kosovo should use this benefit in order to increase trade exchanges with Turkish firms.

As for the second hypothesis, the population is significant only in the second model. The second model concerns Turkey's imports from the Western Balkans. In terms of Turkish imports, this variable is significant, so it can be said that the population is a significant indicator only in terms of Turkish imports. The second hypothesis is not supported. The third hypothesis is supported because the statistical results show that GDP is a significant variable. So the economic size of these countries affects the trade relations between them. In this case, Turkey is in the lead over the countries of the Western Balkans because its economic size is much larger than that of the countries of the Western Balkans.

\section{CONCLUSION}

Trade and FDI are important elements of Turkey's foreign policy. Through economic influence, Turkey aims to increase its presence in many regions where the Ottoman Empire previously ruled. The Western Balkans region is one of the regions where Turkey aims to increase its economic and trade influence even more. As can be understood from the theoretical evidence provided in this paper, this region is of particular importance because it is a bridge between Turkey and the European Union. Therefore, since the beginning of the nineties, Turkey has been actively dealing with the solution of the ethnic and political problems of these countries on the one hand, as well as with the expansion of economic and trade influence in these countries on the other hand.

The processing through gravity model of the ten-year data of economic and trade indicators of these countries provided us with empirical results which prove that the economic size of these countries, geographical distance, common language, and population have an impact on bilateral trade between Turkey and this region. But despite Turkish foreign policy claiming that the Western Balkans are of particular economic and trade importance, official statistics show that Turkey trades more with the European Union, China, and Russia than with the Western Balkans. The countries of the Western Balkans also trade more with the European Union, which is their main trading partner, than with Turkey. Turkish businesses prefer to trade with businesses from Romania, Russia, Bulgaria, the Middle East than with those in the Western Balkans. 
The reasons for this may be the small market and the lack of rule of law in these countries of this region. Therefore, if we look beyond the foreign policy rhetoric, the countries of the Western Balkans should support businesses that export to the Turkish market in increasing their export capacity, inform other businesses about export opportunities in the Turkish market, advantages of this market, etc. Meanwhile, the relevant institutions of Turkey should draft separate action plans for each of these six countries of the Western Balkans. Turkish businesses that export to these countries should be supported through specific strategies and plans for each country where the origin of the export is. Exporting businesses generate the influence of Turkish policy in the Western Balkans, not construction sector businesses that build projects for several months and then return to Turkey.

Turkish products are mostly found in the markets of North Macedonia and Albania, but every effort should be made to find Turkish products everywhere in the markets of the Western Balkans. Despite the fact that Turkish foreign policy envisages the Western Balkans as a strategic point where Turkish economic influence should be expanded, Turkish businesses do not see this region as very attractive as a market. Therefore, it is not enough only for foreign policy to see this region as attractive, but there should be greater interest from Turkish businesses for this region in order to meet the main strategic objectives of Turkish foreign policy towards the Western Balkans.

Future research should focus on elaborating trade between the Western Balkans and Turkey over longer periods. In our research, we have studied this issue for a period of 10 years, while future research should focus on periods of 20 years or even 30 years. Future research should also include other variables which have not been studied so far by the gravity model. For example, variables related to diplomatic relations between Turkey and the Western Balkan countries can be included in the research, such as the period of diplomatic cooperation, activities of embassies to promote free trade, etc., are some of the interesting variables of which would arouse the curiosity of future readers.

\section{LITERATURE}

1. Abazi, E.: Kosovo Independence: An Albanian Perspective, SETA Foundation for Political, Economic and Social Research, (11) 2008, p. 1-5.

2. Akan, M. D. H., Engin-Balın, B.: The European Union-Turkey Trade Relations under the Influence of Customs Union, Journal of Economics, Business and Management, 4 (2), 2016, p. 155-160.

- DOI: https://doi.org/10.7763/JOEBM.2016.V4.383 
3. Babacan, M.: Whither an Axis Shift: A Perspective from Turkey's Foreign Trade, Insight Turkey, 13 (1) 2011, p. 155.

4. Babuna, A.: European Integration, Bosnia-Herzegovina and Stability in the Western Balkans: A New Strategy, Perceptions, 19 (2) 2014, p. 23.

5. Bechev, D.: Turkey in the Balkans: Taking a Broader View, Insight Turkey, 14 (1) 2012, p. 139.

6. Beck, N., Katcz, N. J.: What to do (And not to do) with time-series cross-section data, American Political Science Review, 89 (3) 1995, p. 634-647.

- DOI: https://doi.org/10.2307/2082979

7. Bieber, F., Tzifakis, N.: The Western Balkans as a Geopolitical Chessboard? Myths, Realities and Policy Options, Balkans in Europe Policy Advisory Group, 2019, p. 5-30.

- DOI: https://doi.org/10.4324/9780429243349

8. Bieber, F.: Patterns of competitive authoritarianism in the Western Balkans, East European Politics, 34 (3) 2018, p. 337-350.

- DOI: https://doi.org/10.1080/21599165.2018.1490272

9. Bilgin, P.: Securing Turkey through western-oriented foreign policy, New perspectives on Turkey, (40) 2009, p. 105-125.

- DOI: https://doi.org/10.1017/S0896634600005239

10. Brljavac, B.: Turkey Entering the European Union through the Balkan Doors: In the Style of a Great Power!?, Polemos: Journal of Interdisciplinary Research on War and Peace, 14 (27) 2011, p. 523.

11. Çakır, M.: An Economic Analysis of the Relationship between Turkey and the Balkan Countries, ADAM AKADEMİ, 4 (2) 2014, p. 77-86.

12. Civan, A. et al:: The Effect of New Turkish Foreign Policy on International Trade, Insight Turkey, 15 (3) 2013, p. 107-122.

13. Dabrowski, M., Myachenkova, Y.: Research Report: The Western Balkans on the road to the European Union. Bruegel Policy Contribution, No. 4, Bruegel, Brussels, 2018, p. 4.

14. Dursun-Özkanca, O.: Turkey and the European Union: Strategic Partners or Competitors in the Western Balkans?, Journal of Regional Security, 11 (1) 2016, p. 44.

15. Ekinci, U. M.: A Golden Age of Relations: Turkey and the Western Balkans During the AK Party Period, Insight Turkey, 16 (1) 2014, p. 103-125

16. Ekmen-Özçelik, S.: Trade Potential Between Balkan Countries And Turkey, International Balkan and Near Eastern Social Sciences Conference Series- IBANESS Conference Series-Prilep/Republic of Macedonia, 2016, p. 187-193

17. Enwere, Ch., Yilmaz, M.: Turkey's Strategic Economic Relations with Africa: Trends and Challenges, Journal of Economics and Political Economy, 1 (2) 2014, p. $215-230$. 
18. Gashi, P. et al.: Kosovo - EU Trade Relations: A Dynamic Panel Poisson Approach, Applied Economics, 49 (27) 2017, p. 2642-2654.

- DOI: https://doi.org/10.1080/00036846.2016.1245836

19. Gashi, P., Berisha, B.: The Impact of $100 \%$ Tariff on the Import of Goods from Serbia and Bosnia and Herzegovina, European Union: Kosovo, No. 2018/395320, 2019, p. 21.

20. Gashi, P., Pugh, G.: Kosovo's Trade with the European Union: Looking beyond the Stabilisation and Association Agreement, Kosovo Foundation for Open Society KFOS, 2015, p. 8-82.

21. Gashi, P.: Free Trade and FDI in Kosovo: Prospects for Integration into the EU and Turkish Production Networks, Turkish Economic Review, 4 (1) 2017, p. 86.

22. Gashi, P.: Human Capital and Export Decisions: The Case of Small and Medium Enterprises in Kosovo, Croatian Economic Survey, 16 (2) 2014, p. 91-120

23. Gökgöz, A. et al.: Analysis of International Trade between Turkey and Croatia, Poslovna izvrsnost/Business Excellence, 10 (2) 2016, p. 156.

24. Gümüşcan, I., Kahveci, M.: An Evaluation of Bilateral Trade between Turkey and Balkans: Based on Gravity Trade Model and Linder Hypothesis 241. IBACİstanbul Üniversitesi, 1, 2012, p. 361-371.

25. Hake, M., Radzyner, A.: Western Balkans: Growing economic ties with Turkey, Russia and China, Bank of Finalnd \& BOFIT Institute for Economies in Transition, 2019, p. 4-17.

26. Halili, Z.: Western Balkans Integration into European Union: Challenges and Consequences, Traektoriâ Nauki = Path of Science, 5 (8) 2019, p. 4001-4012.

- DOI: https://doi.org/10.22178/pos.49-5

27. Harxhi, E.: An Overview of Turkish Foreign Policy in the Balkans, Insight Turkey, 19 (1) 2017, p. 33-42.

- DOI: https://doi.org/10.25253/IT.2017.19201

28. International Trade Centre: Bilateral trade between Turkey and Albania, Bosnia and Herzegovina, Kosovo, North Macedonia, Montenegro and Serbia in 2019, retrieved August 22, 2020.

29. Jusufi, G. et al.: The effect of product innovation on the export performance of Kosovo SMEs, Management: Journal of Contemporary Management Issues, 25 (2) 2020, p. 215-234.

- DOI: https://doi.org/10.30924/mjcmi.25.2.12

30. Jusufi, G., Ajdarpašić, S.: The Impact of EU Programmes on Financing Higher Education Institutions in Western Balkans - Evidence from Kosovo, LEXONOMICA Journal of Law and Economics, 12 (1) 2020, p. 125.

- DOI: https://doi.org/10.18690/lexonomica.12.1.107-128.2020 
31. Jusufi, G., Bellaqa, B.: Trade Barriers and Exports between Western Balkan Countries, Naše Gospodarstvo/Our Economy, 65 (4), 2019, p. 74.

- DOI: https://doi.org/10.2478/ngoe-2019-0021

32. Jusufi, G., Lubeniqi, G.: An Overview of Doing Business in Western Balkan: The Analysis of Advantages of Doing Business in Kosovo and North Macedonia, ILIRIA International Review, 9 (2) 2019, p. 168.

33. Jusufi, G., Ukaj, M.: Migration and Economic Development in Western Balkan Countries: Evidence from Kosovo, Poslovna Izvrsnost/Business Excellence, 14 (1) 2020, p. 142.

- DOI: https://doi.org/10.22598/pi-be/2020.14.1.135

34. Kaloyanchev, P. et al.: Untapped Potential: Intra-Regional Trade in the Western Balkans, European Commission, (080) 2018, p. 20.

35. Karagoz, K., Saray, M. O.: Trade Potential of Turkey with Asia-Pacific Countries: Evidence from Panel Gravity Model, International Economic Studies, 36 (1) 2010, p. 19-26.

36. Kastrati, A. et al.: Output gap in Transition Economies using Unobserved Component Method: The Case of Czech Republic, Estonia and Kosovo, Ekonomska Misao i Praksa/Economic Thought and Practice, (2) 2017, p. 477-500.

37. Kastrati, A.: The role of civil society in the European integration process in Kosovo: EU Mechanisms and instruments for NGO sector development. 37th International Academic Conference, Budapest, 2018, p. 55.

- DOI: https://doi.org/10.20472/IAC.2018.037.009

38. Kirişci, K.: The transformation of Turkish foreign policy: The rise of the trading state, New Perspectives on Turkey, (40), 2009, p. 29-57.

- DOI: https://doi.org/10.1017/S0896634600005203

39. Kocaslan, G. et al.: Is a Regional Trade Agreement with Balkan Countries Applicable for Turkey? A Time Series Analysis. Journal of Economic and Social Studies, 4 (1) 2014, p. 25-37.

- DOI: https://doi.org/10.14706/JECOSS11412

40. Kursunluoglu-Yarimoglu, E., Gur, E.: Entry Mode to Western Balkans: An Implementation in Albania and Kosovo Markets, Mustafa Kemal University Journal of Graduate School of Social Sciences, 13 (33) 2016, p. 258-275.

41. Kutlay, M.: Economy as the 'Practical Hand' of 'New Turkish Foreign Policy': A Political Economy Explanation, Insight Turkey, 13 (1) 2011, p. 67-88.

42. Lami, B.: Influence of Turkish Foreign Policy in Albania, European Journal of Multidisciplinary Studies, 2 (1) 2017, p. 99.

- DOI: https://doi.org/10.26417/ejms.v4i1.p98-106

43. Lushaku-Sadriu, J.: Europeanisation through Conditionality and Deliberation, Australian and New Zealand Journal of European Studies, 11 (2) 2019, pp. 33.

- DOI: https://doi.org/10.30722/anzjes.vol11.iss2.15117 
44. Mitrovic, M.: Turkish Foreign Policy towards the Balkans: The influence of traditional determinants on Davutoğlu's conception of Turkey - Balkan relations, GeT MA Working Paper, Department of Social Scienc-es, Humboldt-Universität zu Berlin, (10), 2014, p. 62.

45. Muja, M., Gunar, S.: Institutions and economic performance: Evidence from Western Balkans 1996-2016, IFAC-PapersOnLine, 52 (25) 2019, p. 287-292.

- DOI: https://doi.org/10.1016/j.ifacol.2019.12.497

46. Öniş, Z.: Multiple Faces of the "New" Turkish Foreign Policy: Underlying Dynamics and a Critique, Insight Turkey, 13 (1) 2011, p. 47-65.

47. Park, M.H.: Practical Guides to Panel Data Modeling: A Step by Step Analysis Using Stata, International University of Japan Public Management \& Policy Analysis Program, 2011, p.1.

48. Peci, F. et al.: Determinants of Kosovo Trade: A Gravity Model Approach, South East European Journal of Economics and Business, 5 (2) 2010, p.37.

- DOI: https://doi.org/10.2478/v10033-010-0013-4

49. Petrović, Ž., Reljić, D.: Turkish Interests and Involvement in the Western Balkans: A Score-Card, Insight Turkey, 13 (3) 2011, p.159-172.

50. Qorraj, G., Jusufi, G.: Does EU Trade Integration Support Export Promotion: Probit Analysis, Evidence from Kosovo, InterEULawEast: Journal for the International and European Law, Economics and Market Integrations, 8 (1) 2021, 75-90.

- DOI: https://doi.org/10.22598/iele.2021.8.1.5

51. Qorraj, G., Jusufi, G.: EU vs Local Market Orientation: Western Balkan Entrepreneurs' Challenge, Entrepreneurial Business and Economics Review, 7(4) 2019, p. 22

- DOI: https://doi.org/10.15678/EBER.2019.070402

52. Qorraj, G., Jusufi, G.: The EU Stabilisation and Association Agreement for the Western Balkans: Between Challenges and Opportunities, Croatian International Relations Review, 24 (81) 2018, p. 51-68.

- DOI: https://doi.org/10.2478/cirr-2018-0003

53. Qorraj, G.: Towards European Union or Regional Economic Area: Western Balkans at Crossroads, Naše Gospodarstvo/Our Economy, 64 (1) 2018, p. 15.

- DOI: https://doi.org/10.2478/ngoe-2018-0002

54. Rašidagić, K.E., Hesova, Z.: Development of Turkish Foreign Policy Towards the Western Balkans with Focus on Bosnia and Herzegovina, Croatian International Relations Review, 26 (86) 2020, p. 98.

- DOI: https://doi.org/10.37173/cirr.26.86.4

55. Rašidagić, K.E.: A Critical Analysis of Turkish Foreign Policy towards the Western Balkans, Turkish - Balkans Relations: The Future Prospects of Cultural, Political and Economic Transformations and Relations, 2013. 
56. Remiddi, A.: Turkey in the Western Balkans: Between Orientalist Cultural Proximity and Re-Orientation of Regional Equilibria, Balkan Social Science Review, 1,2013 , p. 228

57. Sallova, D.: The denationalization Policy of the International Community in Kosovo, Thesis, 8 (1) 2019, p.159.

58. Sandalcilar, R.A.: Turkey's Trade Potential with the BRIC Countries: The Panel Gravity Model Approach, Journal of Yasar University, 75 (5) 2012, p. 4165-4175.

59. Sela, S., Shabani, L.: The European Union Politics in the Western Balkans, The Western Balkans Policy Review, 1 (2) 2011, p. 24.

- DOI: https://doi.org/10.1515/seeur-2015-0032

60. Sela, Y., Maksuti, B.: The Social, Political and Economic changes in the Western Balkans: Managing diversity, SEEU Review, 11 (2), 2015, p. 110.

61. Sen, A. et al.: Intra-Industry Trade between Turkey and OECD Countries: A Panel Data Analysis, Zagreb International Review of Economics \& Business, 12 (2) 2009, p. 73-86.

62. Shkurti, G., Ozcan, S.: Main Challenges and Features of Democratization in the Balkans: Albania case, International Conference on Economic and Social Studies ICESOS'14, 2014, p. 195.

63. Šorović, M.: Importance and role of Turkey in the Western Balkans, Research in Social Change, 10 (2) 2018, p. 88-89.

64. Stojcic, N. et al:: Creativity, innovation effectiveness and productive efficiency in the UK, European Journal of Innovation Management, 21 (4) 2018, p. 564-580.

- DOI: https://doi.org/10.1108/EJIM-11-2017-0166

65. Tahirovic, M.: Relations between Turkey and the Balkan Countries as in a Function of Improving the Regional Peace and Stability, Adam Akademi, 4 (2) 2014, p. 10.

66. Taşbaş1, A.: International trade and strategic behaviour: A game theoretical analysis of the trade dispute between Turkey and Russia, Economic Research/ Ekonomska Istraživanja, 30 (1) 2017, p. 581.

67. Türbedar, E.: Turkey's New Activism in the Western Balkans: Ambitions and Obstacles, Insight Turkey, 13 (3) 2011, p. 149.

68. Ülengin, F. et al.: Effects of quotas on Turkish foreign trade: A gravity model, Transport Policy, 2015.

- DOI: https://doi.org/10.1016/j.tranpol.2014.09.006

69. Vračić, A.: Turkey's role in the Western Balkans, Berlin: Stiftung Wissenschaft und Politik -SWP- Deutsches Institut für Internationale Politik und Sicherheit, 2016, p. 13.

70. Yaşar, E., Korkaz, I.: Analysis of Foreign Trade between Turkey and the Balkan Countries with Gravity Model, The Journal of Kesit Academy, 3 (10) 2017, p. 382-407.

- DOI: https://doi.org/10.18020/kesit.1276 
71. Direction in Googlemap, retrieved August 30, 2020 from https://www.google.com/ maps/dir/Ankara,+Turkey/Skopje,+North+Macedonia/@41.2729942,22.6519434, $6 \mathrm{z} /$ data $=! 3 \mathrm{~m} 1 ! 4 \mathrm{~b} 1 ! 4 \mathrm{~m} 14 ! 4 \mathrm{~m} 13 ! 1 \mathrm{~m} 5 ! 1 \mathrm{~m} 1 ! 1 \mathrm{~s} 0 \times 14 \mathrm{~d} 347 \mathrm{~d} 520732 \mathrm{db} 1: 0 \times \mathrm{xdc} 57 \mathrm{~b} 0 \mathrm{c}$ $0842 \mathrm{~b} 8 \mathrm{~d} ! 2 \mathrm{~m} 2$ !1d32.8597419!2d39.9333635!1m5!1m1!1s0x135415a58c9aa2a 5:0xb2ed88c260872020!2m2!1d21.4254355!2d41.9981294!3e0

72. Eurostat, GDP and main components, retrieved September 2, 2020 from https:// appsso.eurostat.ec.europa.eu/nui/show.do?dataset=nama_10_gdp\&lang=en

73. Eurostat, GDP and main components, retrieved September 2, 2020 from https:// appsso.eurostat.ec.europa.eu/nui/show.do?dataset=nama_10_gdp\&lang=en

74. Eurostat, GDP and main components, retrieved September 2, 2020 from https:// appsso.eurostat.ec.europa.eu/nui/show.do?dataset=nama_10_gdp\&lang=en

75. Eurostat, Population on 1 January, retrieved September 4, 2020 from https:// ec.europa.eu/eurostat/databrowser/view/tps00001/default/table?lang=en

76. Eurostat, Population on 1 January, retrieved September 4, 2020 from https:// ec.europa.eu/eurostat/databrowser/view/tps00001/default/table?lang=en

77. Eurostat, Population on 1 January, retrieved September 4, 2020 from https:// ec.europa.eu/eurostat/databrowser/view/tps00001/default/table?lang=en

78. Turkish Statistical Institute, Foreign Trade by Partner Country. Retrieved August 24, 2020 from https://biruni.tuik.gov.tr/disticaretapp/disticaret_ing.zul?param1= $4 \&$ param $2=0 \&$ sitcrev $=0 \&$ isicrev $=0 \&$ sayac $=5908$

79. Turkish Statistical Institute, Foreign Trade by Partner Country. Retrieved August 24, 2020 from https://biruni.tuik.gov.tr/disticaretapp/disticaret_ing.zul?param1= $4 \&$ param $2=0 \&$ sitcrev $=0 \&$ isicrev $=0 \&$ sayac $=5908$

80. Turkish Statistical Institute, Foreign Trade by Partner Country. Retrieved August 24, 2020 from https://biruni.tuik.gov.tr/disticaretapp/disticaret_ing.zul?param1= $4 \&$ param $2=0 \&$ sitcrev $=0 \&$ isicrev $=0 \&$ sayac $=5908$ 